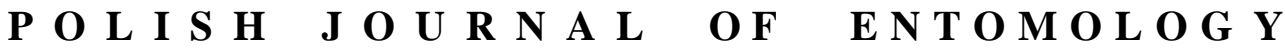

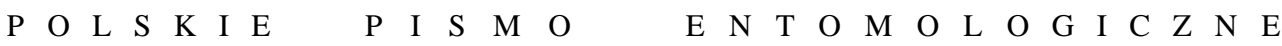

VOL. 85: $437-451$

Lublin

31 December 2016

DOI: $10.1515 /$ pjen-2016-0028

\section{Biological control of thrips pests (Thysanoptera: Thripidae) in a commercial greenhouse in Hungary}

\author{
PÉTER FARKAS ${ }^{1 *}$, NÓRA BAGI ${ }^{1}$, ÁRPÁd SZABÓ ${ }^{1}$, MÁRTA LADÁNYI $^{2}$, \\ KRISZTIÁNNÉ KIS ${ }^{3}$, ANNAMÁRIA SOJNÓCZKI ${ }^{1}$, DÁNIEL REITER ${ }^{1}$, \\ BÉLA PÉNZES ${ }^{1}$, JÓZSEF FAIL ${ }^{1}$ \\ ${ }^{1}$ Department of Entomology, Faculty of Horticultural Science, Szent István University, \\ Villányi út 29-43, 1118 Budapest, Hungary \\ ${ }^{2}$ Department of Biometrics and Agricultural Informatics, Faculty of Horticultural Science, \\ Szent István University, Villányi út 29-43, 1118 Budapest, Hungary \\ ${ }^{3}$ Vegetable Growing Sector, Experimental and Research Farm, Faculty of Horticultural \\ Science, Szent István University, 1734 Budapest, Pf. 18., Hungary
}

\begin{abstract}
Polyphagous thrips, like western flower thrips Frankliniella occidentalis and onion thrips Thrips tabaci, are major pests in various ornamental and vegetable crops in greenhouses throughout the world. In Hungary, both of these polyphagous thrips species frequently cause severe damage in many greenhouse crops, especially in commercial sweet pepper. Chemical control is not always feasible because of certain ecological characteristics of these thrips species. The commercially available phytoseiid predatory mites like Amblyseius swirskii and anthocorid flower bugs like Orius laevigatus are often used simultaneously for the biological control of severe thrips infestation in sweet pepper cultivation in Hungary. Our observations demonstrated that the polyphagous thrips assemblages were effectively controlled by the combined release of natural enemies, despite the fact that the establishment of $O$. laevigatus did not seem to be successful in the first year. Overall, the thrips population density remained below the economic threshold in both years. However, the low infestation level of thrips suggests that a single predator release strategy could be applied effectively and still maintain the thrips below the damage threshold in greenhouse sweet pepper.
\end{abstract}

KEY WORDS: biological control, greenhouse sweet pepper, Amblyseius swirskii, Orius laevigatus, thrips.

\footnotetext{
*Corresponding author: Farkas.Peter@kertk.szie.hu
} 


\section{INTRODUCTION}

Polyphagous thrips, like western flower thrips Frankliniella occidentalis (PERGANDE, 1895) (Thysanoptera: Thripidae) and onion thrips Thrips tabaci LINDEMAN, 1889 (Thysanoptera: Thripidae), are key pests in various ornamental and vegetable crops in greenhouses worldwide. Since Frankliniella occidentalis was first reported in Hungary on various cut flowers in 1989 (JENSER \& TUSNÁDI 1989), western flower thrips have become the most dangerous thrips pest of protected crops in Hungary (HATALA ZSELLÉR \& KISS 1999, MOLNÁR et al. 2008). Thrips infestations can cause serious economic losses by their direct damage and by transmitting Tomato Spotted Wilt Virus (TSWV). Both of these polyphagous thrips species frequently cause severe damage in many greenhouse crops, especially in commercial sweet pepper. Sweet pepper (Capsicum annuиm L.) is the most important greenhouse crop in Hungary: it is grown on approximately 2000 hectares. Growers most often produce traditional Hungarian cultivars (HATALA ZSELLÉR 1992, TOMPOS 2006), where the success of plant protection is based on the management of thrips. Chemical control is not always feasible because of certain ecological characteristics of these thrips species: thigmotactic behaviour, high reproductive capacity and tolerance to insecticides. The efficiency of thrips management in sweet pepper could be improved by using predatory arthropods like the predatory mite Amblyseius swirskii ATHIAS-HENRIOT, 1962 (Acari: Phytoseiidae) and the flower bug Orius laevigatus FIEBER, 1860 (Hemiptera: Anthocoridae), which are economically successful alternatives to chemical pest control within the framework of augmentative biological control (VAN LENTEREN \& BUENO 2003). Biological pest control is most economical in long-period forcing, when a growing period can last for up to 8-10 months. Numerous domestic pepper growers have already changed to soilless, nutrient solution cultures, where the cultivar almost exclusively used is the conical, white-fleshed 'HÓ-F1'. This is the favourite cultivar type in Hungary but also the most susceptible to damage by thrips species (MOLNÁR et al. 2008). Therefore in Hungary, key biocontrol agents like Amblyseius swirskii and Orius laevigatus are widely used for the control of thrips pests by most sweet pepper growers as part of Integrated Pest Management.

Amblyseius swirskii is a beneficial predatory mite, native to the eastern Mediterranean region (RAGUSA \& SWIRSKI 1977). Many studies have shown that the omnivorous A. swirskii can feed and reproduce on a wide range of food sources, such as greenhouse whitefly (Trialeurodes vaporariorum WESTWOOD, 1856), tobacco whitefly (Bemisia tabaci (GENNADIUS, 1889)), acrid mite (Tyrophagus putrescentiae (SCHRANK, 1781)), broad mite (Polyphagotarsonemus latus (BANKS, 1904)), tomato russet mite (Aculops lycopersici (MASSEE, 1937)), spider mite (Tetranychus urticae KoCH, 1836), chilli thrips (Scirtothrips dorsalis HOOD, 1919) and also feed on the pollen of various plant species (MOMEN \& EL- 
SAWAY 1993, El-ShERIF et al. 1999, NomiKou et al. 2001, 2002, 2004, MesSELINK et al. 2006, 2008, Arthurs et al. 2009, van MAANen et al. 2010, PARK et al. 2010, XU \& ENKegaARD 2010, NOMIKoU et al. 2010, LeE 2011). According to BlOCKMANs et al. (2005) and WIMMER et al. (2008) Amblyseius swirskii is a promising agent in biological control systems because it predates, reproduces and develops on western flower thrips and onion thrips as well. Studies have reported the efficiency of A. swirskii against Frankliniella occidentalis on vegetable crops and also their good control on sweet pepper (VAN Houten et al. 2005, BeLDA \& CALVo 2006, KUTUK et al. 2011).

Orius WOLFF, 1811 species can feed on various kinds of arthropods but display a certain preference for thrips. Their advantage in thrips control is that they prey on both larval and adult thrips (WITTMANN \& LEATHER 1997). The anthocorid bug most commonly used in Europe as an effective biological control agent of western flower thrips is the generalist predator Orius laevigatus (WEINTRAUB et al. 2011, MESSELINK et al. 2012).

The aim of this study was to observe whether the combined release of two biological control agents would be sufficient to supress the phytophagous thrips population in greenhouse sweet pepper.

\section{MATERIAL AND METHODS}

\section{Experimental site}

The trial was conducted at the Experimental and Research Farm, Faculty of Horticultural Science, Corvinus University, Budapest, in 2010 and 2011. The usual unheated growing season for the production of peppers in a Filclair greenhouse extends from mid-April to November under Hungarian climatic conditions. Sweet pepper seedlings were transplanted onto rockwool slabs in a $1500 \mathrm{~m}^{2}$ multi-span Filclair greenhouse on 16 April 2010 and 18 April 2011. This is an air-inflated, double-layer polyethylene greenhouse, $52 \mathrm{~m}$ long and $28.8 \mathrm{~m}$ wide with a gutter height of $3.75 \mathrm{~m}$. The ventilation is controlled by an automatic system that opens or closes the vents. The Capsicum annuиm cv. HÓ F1 sweet pepper variety was planted, an indeterminate hybrid variety (white fruited) that is the most widely used variety in soilless cultivation in Hungary (TOMPOS 2006). The sweet pepper plants were grown in twin rows and spaced apart to a density of 4.04 plants per square metre. The plants were trellised to a two-stem pruning system. Plants were watered and fertilized by a drip irrigation system, according to standard grower's practice.

\section{Natural enemies and monitoring}

The biological control strategy was based on the release of Amblyseius swirskii and Orius laevigatus for thrips control and several treatments of $0.1 \%$ Bacillus thuringiensis 
BERLINER, 1915 var. kurstaki were applied to control cotton bollworm (Helicoverpa armigera HÜBNER, 1809). No other pesticides were applied. Dosing and timing of natural enemy releases were determined by the local distributor and beneficial arthropods were released when the pepper plants started flowering in both years. The release rates and times in both years are shown in Table 1.

Table 1. Timing and release rates for natural enemies in 2010 and 2011.

\begin{tabular}{|c|c|c|c|r|}
\hline \multicolumn{2}{|c|}{ Release time } & Natural enemies & Type of product & Release rate \\
\hline \multirow{4}{*}{2010} & \multirow{2}{*}{ May } & A. swirskii & Swirskii Mite Plus & $167 / \mathrm{m}^{2}$ \\
\cline { 2 - 5 } & & O. laevigatus & Thripor $^{\mathrm{TM}}$ & $1.3 / \mathrm{m}^{2}$ \\
\cline { 2 - 5 } & 14 May & A. swirskii & Swirskii-Mite $^{\mathrm{TM}}$ & $33.3 / \mathrm{m}^{2}$ \\
\cline { 2 - 5 } & 20 May & O. laevigatus & Thripor $^{\mathrm{TM}}$ & $0.7 / \mathrm{m}^{2}$ \\
\cline { 2 - 5 } & 19 August & O. laevigatus & Thripor $^{\mathrm{TM}}$ & $1 / \mathrm{m}^{2}$ \\
\hline \multirow{2}{*}{2011} & 12 May & A. swirskii & Swirskii Mite Plus $^{\mathrm{TM}}$ & $83 / \mathrm{m}^{2}$ \\
\cline { 2 - 5 } & 19 May & O. laevigatus & Thripor $^{\mathrm{TM}}$ & $2 / \mathrm{m}^{2}$ \\
\hline
\end{tabular}

The predatory mites and bugs were produced by Koppert Biological Systems (Netherlands). Amblyseius swirskii was packaged in paper sachets (Swirskii-Mite Plus ${ }^{\mathrm{TM}}$ ) and in $500 \mathrm{ml}$ bottles (Swirskii-Mite ${ }^{\mathrm{TM} \otimes}$ ). The mites were released by hanging the paper sachets in the first branch of the pepper plants to distribute the predatory mites in the crop. When the bottle shipment was applied the mites were sprinkled from the bottle onto the surface of the pepper leaves. The anthocorid bug was supplied in bottles (Thripor ${ }^{\mathrm{TM} \otimes}$ ) and the bugs were released uniformly on the surface of the pepper leaves with the carrier materials.

Bacillus thuringiensis var. kurstaki was applied on 15 June, 11 and 17 July, 2 and 16 August in 2010, and on 9 and 21 July, 4 August in 2011 to prevent damage of the cotton bollworm.

\section{Sampling}

The arthropods were collected by picking flowers directly into plastic vials separately containing 70\% ethanol. 50 open blooms were randomly chosen and collected every 14 days from the entire area to monitor the thrips and predator populations, 9 and 11 times in 2010 and 2011, respectively. From the samples, thrips and mites were mounted on separate microscope slides for each flower and identified to species using a compound microscope. Adult thrips were identified based on the identification guide of MOUND \& KIBBY (1998) and the key of MORITZ et al. (2001). Juvenile stages of thrips were distinguished and the L2 
stages were identified using the key by VIERBERGEN et al. (2010). Predatory mites were identified using the key by SWIRSKI et al. (1998). The adults of the bugs collected were identified using PÉRICART's (1972) guide.

\section{Statistical analysis}

Statistical analysis was carried out using IBM SPSS 22 software. The abundance of different arthropod species (Amblyseius swirskii, Orius laevigatus, thrips species) was monitored during the entire production period and analysed using a one-way repeated measures ANOVA model with species impact as a factor. In order to normalize the data 10 x 20 flowers were selected at random from each sample of 50 flowers. The sum of the individuals observed in the 20 chosen flowers was calculated for all species.

As the assumption of sphericity was violated (2010: $\varepsilon=0.64,2011: \varepsilon=0.64)$, we applied Greenhouse-Geisser's degrees of freedom correction (GEISSER \& GREENHOUSE 1958) to test for within-subjects effects. Normality of residuals was proven according to skewness and kurtosis (TABACHNICK \& FIDELL 2012). Homogeneity of variances was tested by Levene's test ( $p>0.05)$ and, depending on its significance level, within-subjects effect analysis was followed by Tukey's or Games-Howell's post hoc test to detect homogeneous groups of species at different observation times. Pairwise comparisons to explore the observation time effects were made using Bonferroni's test.

\section{RESULTS}

\section{Proportion of thrips species in sweet pepper flowers}

We found 6 thrips species in the sweet pepper flowers in 2010, most frequently Thrips flavus SCHRANK, 1776 (41.7\%), Thrips tabaci (25.3\%), Frankliniella intonsa TRYBOM, $1895(22.9 \%)$ (Fig. 1). Adults of Frankliniella occidentalis were not found in the flowers at all. In the same greenhouse in 2011, Thrips tabaci (90.3\%) was the dominant thrips species and the most dangerous pest of sweet pepper, Frankliniella occidentalis was not encountered at all throughout the growing season (Fig. 2). 

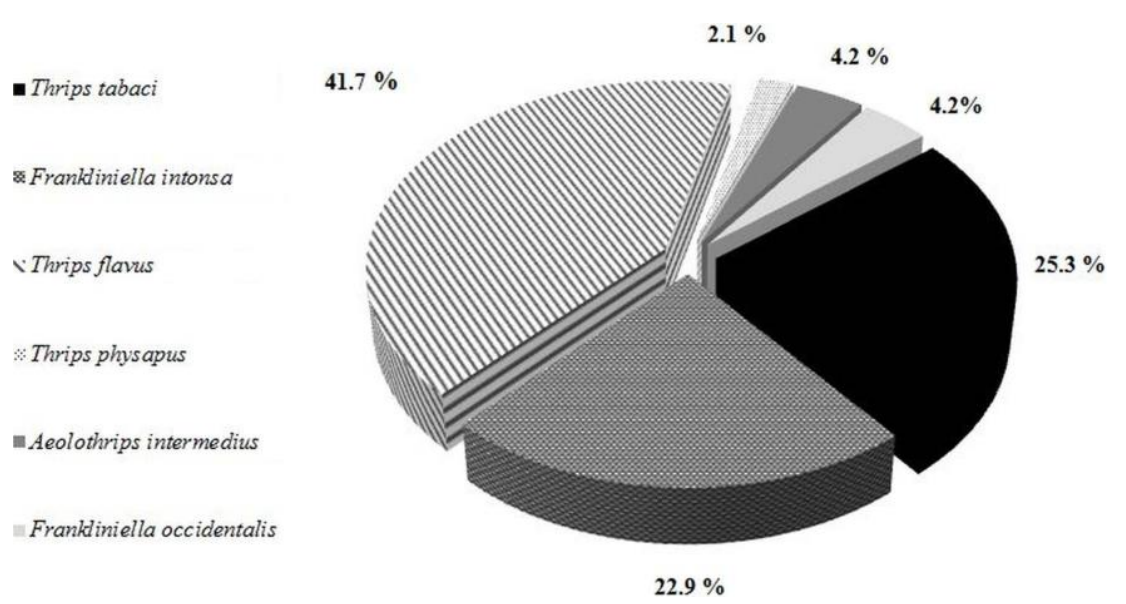

Fig. 1. Proportion of thrips species in flowers of greenhouse sweet pepper in 2010.

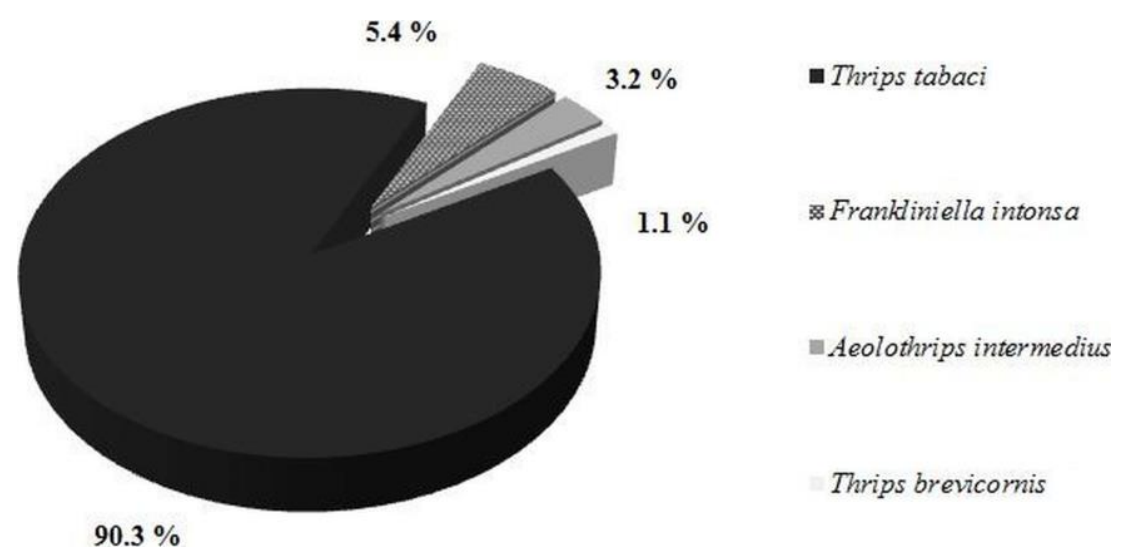

Fig. 2. Proportion of thrips species in flowers of greenhouse sweet pepper in 2011.

\section{Trend of the predatory arthropods and thrips assemblages}

The effect of observation time was significant $\left(\mathrm{F}_{\text {time }}(5.14 ; 138.8)=30.22 ; \mathrm{p}<0.001\right)$ in 2010. The density of thrips species was nearly 0.1 thrips per flower from the beginning of sampling and remained at this level until the middle of August. The abundance of predatory arthropods reached its maximum in June and July, after which it started to decline steeply, and on 12 August we did not find any predatory bug in the samples (Fig. 3). The density of thrips started to rise slightly in late August ( 0.5 per flower) followed by an increase in the abundance of Amblyseius swirskii, but the population density of the predatory bug remained at a low level despite its repeated introduction on 19 August; this release was made because the predator had apparently not established itself (Fig. 3). 


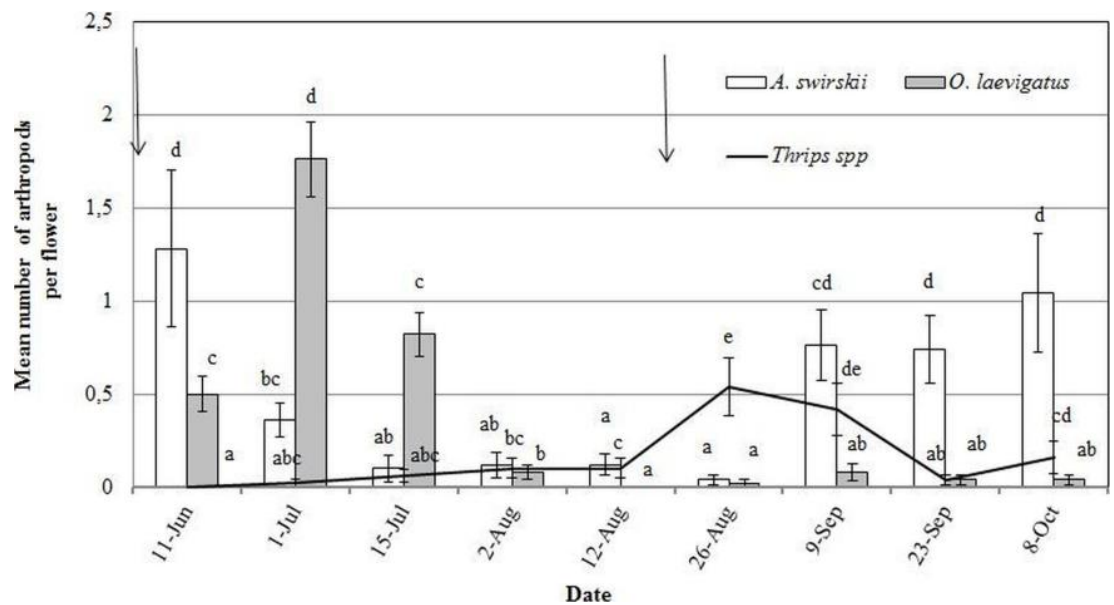

Fig. 3. Trend and mean $( \pm$ SE) numbers of the natural enemies and thrips species in flowers of sweet pepper plants in 2010. Standard error bars are indicated. Arrows indicate the predator release dates. Different letters indicate significant difference (Bonferroni's, $\mathrm{p}<0.05$ ).

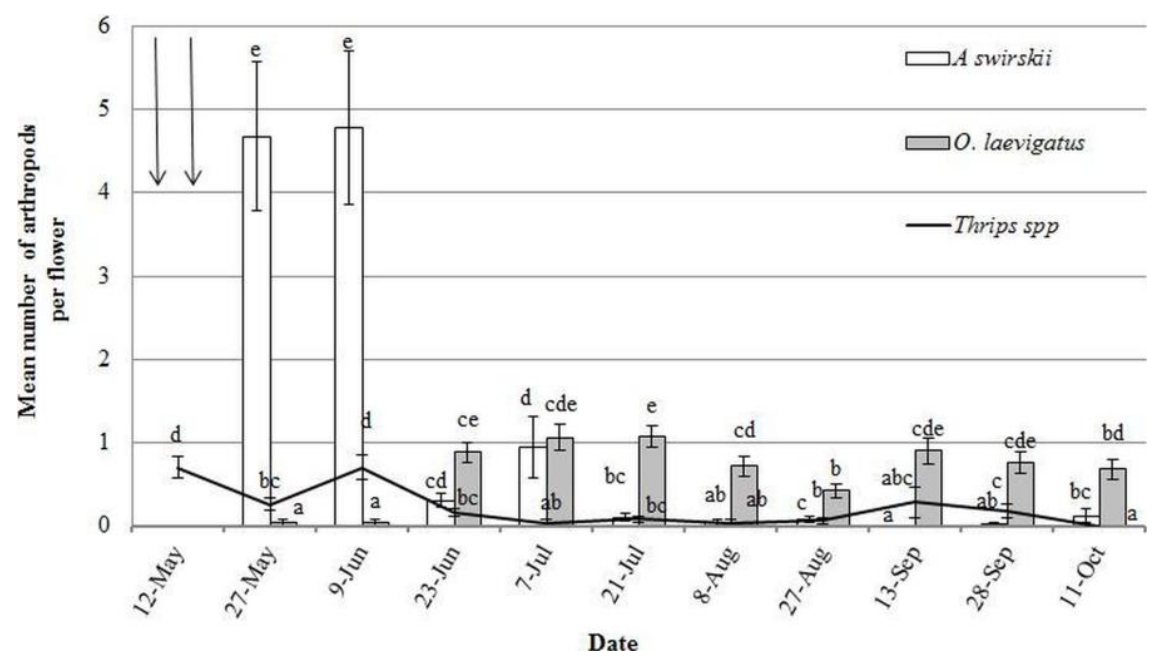

Fig. 4. Trend and mean $( \pm$ SE) numbers of the natural enemies and thrips species in flowers of sweet pepper plants in 2011. Standard error bars are indicated. Arrows indicate predator release dates. Different letters indicate significant difference (Bonferroni's, $\mathrm{p}<0.05$ ).

The effect of time $\left(\mathrm{F}_{\text {time }}(5.73 ; 154.79)=49.29 ; \mathrm{p}<0.001\right)$ was significant in 2011 . When the predators were released in the middle of May the polyphagous thrips had already been present in the crop at an infestation level of 0.7 thrips per flower. Soon after the release of 
predators the thrips population started to decline slowly (from 0.7 to 0.01 per flower) and the number of individuals remained very low from the end of July until the end of the growing season. The predatory mite population attained a peak of 4.78 individuals per flower within 4 weeks of the release and the predatory bug population density reached a level of approximately 1 bug per flower (Fig. 4). From early June to the end of July the abundance of A. swirskii dropped to approximately 1 mite per flower and remained at a very small level ( 0.1 per flower) for the rest of the season, with the exception of the sampling on 13 September, when no predatory mite was found in the pepper flowers. The predatory anthocorid bug population increased a month following its release, after which the population density remained at or slightly below 1 bug per flower.

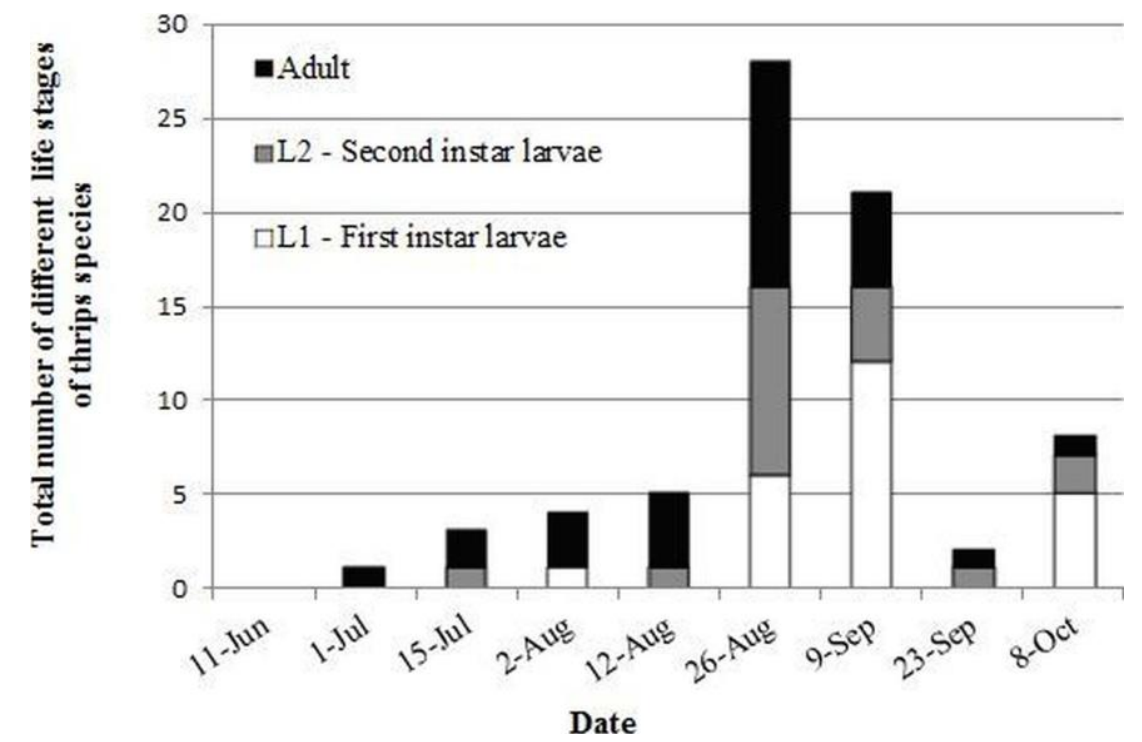

Fig. 5. Population density of different life stages of thrips in 2010.

\section{Abundance of different developmental stages of thrips}

Orius predatory bugs can feed on every feeding stage of thrips but the predatory mites feed primarily on their first instar larvae. In 2010 this vulnerable larval stage was absent or its proportion in the thrips population was extremely low until the end of August, when more first instar larvae were observed in the samples (Fig. 5). Overall, the population density of thrips as available prey for predators was fairly low in 2010. Every feeding stage of thrips was present in most of the samples in 2011, but the proportion of adults was significant until the third decade of June. The overall population density of thrips was 
somewhat bigger at the beginning of sampling than at its peak in 2010, then it dropped to a significantly lower infestation level for the rest of the study (Fig. 6).

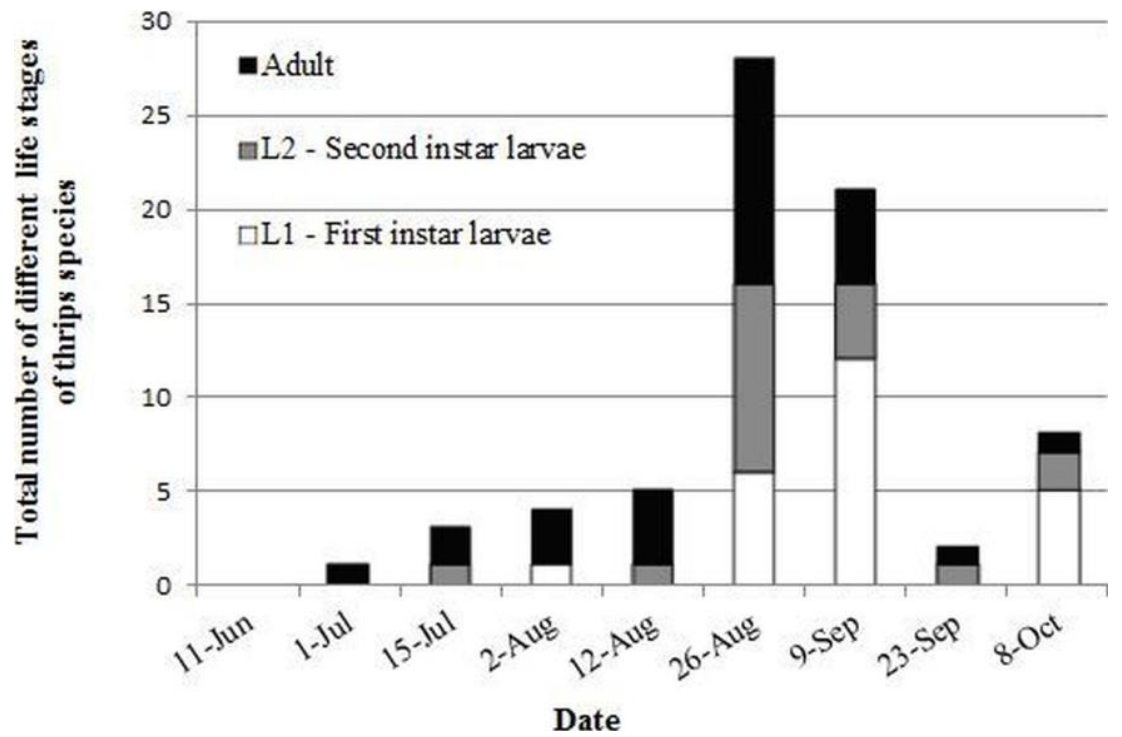

Fig. 6. Population density of different life stages of thrips in 2011.

\section{DISCUSSION}

The overall population density of the thrips assemblages was almost identical in both years and thrips damage to pepper fruits was negligible. But the composition of the thrips assemblages in sweet pepper flowers differed considerably between the years of this study. The species composition in the immediate surroundings of the greenhouse may have been influenced by climatic conditions. The weather conditions were far from normal in 2010: that year was much more humid with extreme levels of precipitation, which could have affected the build-up of thrips populations in the vicinity of the greenhouse. In 2011 weather conditions were much closer to the usual, i.e. hot, dry days for most of the summer. The higher temperature and dry conditions in 2011 could have favoured T. tabaci more than the other species, which were more dominant in 2010, resulting in the absolute dominance of onion thrips. On the basis of OROSZ's (2006) surveys in Hungary, Frankiniella occidentalis and Thrips tabaci occur frequently on numerous weed species (e.g. Taraxacum officinalis (L.) WeBER EX F.H. WigG, Stellaria media (L.) VILL., Trifolium spp.) growing near the greenhouses, and Thrips tabaci larvae were observed on Stellaria media and 
Capsella bursa-pastoris (L.) MEDIK. from the end of April, so they could well have infested greenhouse crops from these weed reservoirs.

A continuously reproducing population of Orius laevigatus was not successfully established on pepper in 2010, possibly due to the lack of sufficient thrips prey $(<0.1$ thrips per flower) in the first half of the season; moreover, this species appeared to have abandoned the greenhouse by the beginning of August. Then the thrips outbreak in the flowers rose to its peak ( 0.54 thrips per flower) until suppressed by Amblyseius swirskii returning from the foliage. This observation is confirmed by the result of SANCHEZ \& LACAZA (2002), namely, that the population of Orius spp. remained at a low level or declined when prey were scarce. We hypothesize that the re-establishment of the predatory mite population in sweet pepper flowers was possible only in the absence of the more competitive predatory bug. The predatory bug was unable to build up an appropriatelysized population and thus contribute to the suppression of thrips pests because of its very small density and slower development. In contrast, the predatory mites in the absence of available thrips prey were able to feed on other arthropod species, for instance on indifferent dust mites present in the crop on the underside of the leaves, next to the main veins, and pepper pollen grains, which were also present on the foliage. They could potentially migrate to the flowers from these reservoirs in the absence of Orius laevigatus.

The predatory mites were present in sweet pepper flowers after their high density introduction for a shorter or a longer period in 2010 and 2011, respectively. Then they seemed to disappear from the flowers, despite reaching a peak population density of about 5 mites per flower and the initial thrips abundance being already 0.7 thrips per flower in 2011. Their disappearance coincided with the build-up of the predatory bug population in both years. Since the population density of first instar thrips larvae did not decline at this time in 2011, it is unlikely that the disappearance of Amblyseius swirskii was driven by the lack of available prey in June. We hypothesize that the increasing presence of the intraguild predator Orius laevigatus is the more likely cause of the decline of the predatory mite population in the flowers. Whether the predatory mites were consumed by the bigger generalist predatory bug or were outcompeted in the flowers and forced to migrate to the foliage remains unclear: our study did not provide any satisfactory evidence regarding this. However, CALVo et al. (2012) came to the same conclusion: they observed larger Orius laevigatus populations in the plots where Amblyseius swirskii was released, possibly due to intra-guild predation by the anthocorid. In addition, URBANEJA et al. (2003) pointed out that the release of Neoseiulus cucumeris (OUDEMANS, 1930) helped Orius laevigatus to become established by providing a supplementary food source, because the anthocorid bug may prey on the predatory mites in the flowers where the bug resides if no other food sources are available. Moreover, CHOw et al. (2010) suggested that Orius will switch to feeding on the most abundant food source. Some other authors also reported the risk following the 
combined release of anthocorids and phytoseiid mites because the bug could be an intraguild predator (JANSSEN et al. 1998, VENZON et al. 2001, SKIRVIN et al. 2007, CHOW et al. 2008, SHAKYA et al. 2009, CHOw et al. 2010). In addition, we recorded that Orius laevigatus nymphs and adults are capable of preying on Amblyseius swirskii under laboratory conditions. We therefore conclude that the continuous presence of the predatory bugs in the sweet pepper flowers in 2011 most likely prevented the re-establishment of A. swirskii population during the remainder of the pepper production period.

Commercially available phytoseiid predatory mites like Amblyseius swirskii and anthocorid flower bugs like Orius laevigatus are often used simultaneously for the biological control of severe thrips infestations in sweet pepper cultivation in Hungary. Our observations demonstrated that the mass proliferation of thrips was effectively prevented by the combined release of natural enemies and was independent of the species composition of Thysanoptera. In both years, its population density was below (mostly $<0.5$ per flower) the estimated economic threshold range of 0.7-2.1 adults or nymphs per flower (PARK et al. 2007). The release ratio and timing was applied with the doses recommended by the distributor and there was no need to use pesticides at all. However, this low infestation level of thrips suggests that a single predator release strategy (presumably Amblyseius swirskii) could have suppressed thrips effectively and maintained their numbers below the threshold in greenhouse sweet pepper, but we have no satisfactory evidence to substantiate this. WEINTRAUB et al. (2011) did not find a significant difference in thrips density in sweet pepper between treatments combining Orius laevigatus and Amblyseius swirskii, although a significant improvement was observed when Amblyseius swirskii was combined with Orius laevigatus in thrips control compared with Amblyseius swirskii released alone or over the untreated plot. The capability of both predators to suppress thrips populations alone in sweet pepper was demonstrated by BELDA \& CALVO (2006), WEINTRAUB et al. (2011), VAN Houten et al. (2005), CHAMBERS et al. (1993), TAVELla et al. (1996) and BosCo et al. (2008). On the other hand, standard grower's practice recommends the combined release strategy for the sake of reducing the incidence of the Tomato Spotted Wilt Virus (CALvo et al. 2012).

In conclusion, the combined use of these two predatory species could offer better security in the management of thrips pests: if one of them is not established successfully in the crop, then the other may still provide efficient control. If there are some other arthropod species damaging the foliage of sweet pepper, e.g. spider mites, broad mites or whiteflies, the presence of Amblyseius swirskii might prove even more useful. In the absence of these pests the release of A. swirskii may be unnecessary, provided the establishment of Orius laevigatus in the crop is successful. In this scenario the more effective predator of anthophilous thrips, O. laevigatus, could force Amblyseius swirskii out of the flowers or 
even consume it. However, if the establishment of Orius laevigatus is unsuccessful, Amblyseius swirskii can respond to increasing thrips pressure by recolonizing the flowers.

\section{ACKNOWLEDGEMENTS}

The authors would like to thank the anonymous reviewers for their helpful comments on the manuscript. The authors were supported by the NKFI (OTKA) K 109594 project.

\section{REFERENCES}

Arthurs S., McKenzie L.C., Chen J., Dogramaci M., Brennan M., Houben K., Osborne L. 2009. Evaluation of Neoseiulus cucumeris and Amblyseius swirskii (Acari: Phytoseiidae) as biological control agents of Scirtothrips dorsalis (Thysanoptera: Thripidae) on pepper. Biological Control 49(1): 91-96.

Belda J.E., Calvo J. 2006. Eficacia de Amblyseius swirskii Athias-HenRiot (Acari: Phytoseiidae) en el control biológico de Bemisia tabaci (GENN.) (Hom.: Aleyrodidae) y Frankliniella occidentalis (PERGANDE) (Thys.: Thripidae) en pimiento en condiciones de semicampo. Boletin de Sanidad Vegetal Plagas 32(2): 283-296.

Blockmans K., van Houten Y., Hoogerbrugge H. 2005. Biological control of whiteflies and western flower thrips in greenhouse sweet peppers with the predatory mite Amblyseius swirskii Athias-Henriot (Acari: Phytoseiidae). [in:] M.S. Hoddle (ed.). FHTET-Publication 2005-08. Proceedings of the Second International Symposium on the Biological Control of Arthropods, September 12-16, 2005, Davos, Switzerland. USDA Forest Service, Morgantown, West Virginia, USA, 555-565.

Bosco L., Giacometto E., Tavella L. 2008. Colonization and predation of thrips (Thysanoptera: Thripidae) by Orius spp. (Heteroptera: Anthocoridae) in sweet pepper greenhouses in Northwest Italy. Biological Control 44(3): 331-340.

Buitenhuis R., ShIPP L., SCOTT-DupREe C. 2010. Intra-guild vs extra-guild prey: effect on predator fitness and preference of Amblyseius swirskii (ATHIAS-HENRIOT) and Neoseiulus cucumeris (OudEMAns) (Acari: Phytoseiidae). Bulletin of Entomological Research 100(2): 167-173.

Calvo F.J., Blockmans K., Belda J.E. 2012. Biological control-based IPM in sweet pepper greenhouses using Amblyseius swirskii (Acari: Phytoseiidae). Biocontrol Science and Technology 22(12): 1398-1416.

Chambers R.J., Long S., Helyer N.L. 1993. Effectiveness of Orius laevigatus (Hem.: Anthocoridae) for the Control of Frankliniella occidentalis on Cucumber and Pepper in the UK. Biocontrol Science and Technology 3(3): 295-307.

Chow A., CHAu A., Heinz K.M. 2008. Compatibility of Orius insidiosus (Hemiptera: Anthocoridae) with Amblyseius (Iphiseius) degenerans (Acari: Phytoseiidae) for control of Frankliniella occidentalis (Thysanoptera: Thripidae) on greenhouse roses. Biological Control 44(2): 259-270.

Chow A., Chau A., HeInZ K.M. 2010. Compatibility of Amblyseius (Typhlodromips) swirskii 
(Athias-HenRiot) (Acari: Phytoseiidae) and Orius insidiosus (Hemiptera: Anthocoridae) for biological control of Frankliniella occidentalis (Thysanoptera: Thripidae) on roses. Biological Control 53(2): 188-196.

El-Sherif A.A., NASR A.K., AbOU-Elela M.M. 1999. Laboratory studies on developmental and oviposition rates of Amblyseius swirskii A-H (Acari: Phytoseiidae) fed on Tyrophagous putrescentiae (SCHRANK) (Acari: Acaridae). Arab Journal of Biotechnology 2(2): 121-126.

GEISSER S., GREENHOUSE S.W. 1958. An extension of Box's results on the use of the F distribution in multivariate analysis. Annals of Mathematical Statistics 29(3): 885-891.

HATAla Zsellér I. 1992. Situation of glasshouse pests in Hungary. EPPO Bulletin 22(3): 411-415.

HATAla ZSELLÉR I., KISS E.F. 1999. Control of Frankliniella occidentalis and TSWV in capsicum crops in Hungary. EPPO Bulletin 29(1-2): 63-67.

JAnSSEn A., PAllini A., Venzon M., SABelis M.W. 1998. Behaviour and indirect interactions in food webs of plant-inhabiting arthropods. Experimental and Applied Acarology 22(9): 497-521.

Jenser G., TusnÁdi Cs. 1989. On the occurrence of Frankliniella occidentalis (PERG.) under field conditions in Hungary. Növényvédelem 25(9): 389-393. (in Hungarian)

LeE H.-S., GillesPIE D.R. 2011. Life tables and development of Amblyseius swirskii (Acari: Phytoseiidae) at different temperatures. Experimental and Applied Acarology 53(1): 17-27.

Messelink G.J., van MaAnen R., van Steenpaal S.E.F., Janssen A. 2008. Biological control of thrips and whiteflies by a shared predator: two pests are better than one. Biological Control 44(3): $372-379$.

MesSELINK G.J., van STEENPAAL S.E.F., RAMAKERS P.M.J. 2006. Evaluation of phytoseiid predators for control of western flower thrips on greenhouse cucumber. BioControl 51(6): 753-768.

Messelink G.J., Sabelis M.W, Janssen A. 2012. Generalist Predators, Food Web Complexities and Biological Pest Control in Greenhouse Crops. [in]: M.L. LARRAmendy, S. SoloneSKI (eds) Integrated Pest Management and Pest Control - Current and Future Tactics. InTech Publishing. Internet: http://www.intechopen.com/books/

MolnÁR A., PAP Z., FAIL J. 2008. Observing population changes of thrips (Thysanoptera) species damaging forced pepper and their natural enemies. International Journal of Horticultural Science 14(4): 55-60.

Momen F.M., El-Saway S.A. 1993. Biology and feeding behaviour of the predatory mite, Amblyseius swirskii (Acari: Phytoseiidae). Acarologia 34(3): 199-204.

Mound L.A., KiBBy G. (1998): Thysanoptera. An identification guide. Second Edition. CAB International, Wallingford.

Moritz G., Morris D., Mound L.A. 2001. ThripsID - Pest thrips of the world. An interactive identification and information system. Cd-rom published by ACIAR, Australia.

Nomikou M., Janssen A., SchraAg R, SABelis M.W. 2002. Phytoseiid predators suppress populations of Bemisia tabaci on cucumber plants with alternative food. Experimental and Applied Acarology 27(1-2): 57-68.

Nomikou M., Janssen A., SchraAg R., SABelis M.W. 2004. Vulnerability of Bemisia tabaci immatures to phytoseiid predators: consequences for oviposition and influence of alternative food. Entomologia Experimentalis et Applicata 110(2): 95-102. 
Nomikou M., Janssen A., Schraag R., Sabelis M.W. 2001. Phytoseiid predators as potential biological control agents for Bemisia tabaci. Experimental and Applied Acarology 25(4): 271-291.

Nomikou M., Sabelis M.W., Janssen, A. 2010. Pollen subsidies promote whitefly control through the numerical response of predatory mites. BioControl 55(2): 253-260.

OROSz Sz. 2006. Investigation of Thysanoptera populations in sweet pepper greenhouses and in their surroundings. Szent István University, Gödöllő (mscr.). (in Hungarian)

PARK H.H., LeE J.H., Uhm K.B. 2007. Economic Threshold of Western Flower Thrips (Thysanoptera: Thripidae) for Unripe Red Pepper in Greenhouse. Journal of Asia-Pacific Entomology 10(1): $45-54$.

PARK H.H., ShiPP L., Buitenhuis R. 2010. Predation, development, and oviposition by the predatory mite Amblyseius swirskii (Acari: Phytoseiidae) on tomato russet mite (Acari: Eriophyidae). Journal of Economic Entomology 103(3): 563-569.

PerICART J. 1972. Hémiptères. Anthocoridae, Cimicidae et Microphysidae de I' Ouest-Paléarctique. Faune de l'Europe et du Bassin Méditerranéen, 7. Masson et Cie., Paris.

RAGUSA S.,SwiRSKI E. 1977. Feeding habits, post embryonic and adult survival, mating, virility and fecundity of the predacious mite Amblyseius swirskii (Acarina: Phytoseiidae) on some Coccids and Mealybugs. Entomophaga 22(4): 383-392.

SANCHEZ J.A., LACAZA A. 2002. Modelling population dynamics of Orius laevigatus and $O$. albidipennis (Hemiptera: Anthocoridae) to optimize their use as biological control agents of Frankliniella occidentalis (Thysanoptera: Thripidae). Bulletin of Entomological Research 92(1): 77-88.

Shakya S., Weintraub P.G., Coll M. 2009. Effect of pollen supplement in intraguild predatory interactions between two omnivores: the importance of spatial dynamics. Biological Control 50(3): 281-287.

Skirvin D.J., Kraver-Garde L., Reynolds K., Jones J., Mead A., Fenlon J. 2007. Supplemental food affects thrips predation and movement of Orius laevigatus (Hemiptera: Anthocoridae) and Neoseiulus cucumeris (Acari: Phytoseiidae). Bulletin of Entomological Research 97(3): 309-315.

SwiRski E., DI Chiara S.R., Tsolakis H. 1998. Keys to the Phytoseiid mites (Parasitiformes, Phytoseiidae) of Israel. Phytophaga Palermo 8: 85-154

TABachnick B.G., Fidell L.S. 2012. Using Multivariate Statistics, 6th ed. Pearson, Boston.

Tavella L., Alma A., Conti A., Arzone A. 1996. Evaluation of the effectiveness of Orius spp. in controlling Frankliniella occidentalis. Acta Horticulturae 431: 499-506.

Tompos D. 2006. CERtain technological elements and economic relationships of greenhouse pepper production on rockwool. PhD thesis. Corvinus University of Budapest (mscr.). (in Hungarian)

Urbaneja A., Leon F.J., Gimenez A., Aran E., van der Blom J. 2003: The interaction of Neoseiulus (Amblyseius) cucumeris (OUdEMANs) (Aca.: Phytoseiidae) on the installation of Orius laevigatus (FIEBER) (Hem.: Anthocoridae) in sweet pepper crops. Boletin de Sanidad Vegetal Plagas 29: 1-12. (in Spanish)

van Houten Y.M., Østlie M.L., Hoogerbrugge H., Blockmans K. 2005. Biological control of western flower thrips on sweet pepper using the predatory mites Amblyseius cucumeris, Iphiseius degenerans, A. andersoni and A. swirskii. Bulletin IOBC/WPRS 28(1): 283-286. 
VAN LENTEREN J.C., BuENO V.H.P. 2003. Augmentative biological control of arthropods in Latin America. BioControl 48(2): 123-139.

van MaAnen R., Vila E., Sabelis M.W., Janssen A. 2010. Biological control of broad mites (Polyphagotarsonemus latus) with the generalist predator Amblyseius swirskii. Experimental and Applied Acarology 52(1): 29-34.

Venzon M., Janssen A., Sabelis M.W. 2001.: Prey Preference, Intraguild Predation and Population Dynamics of an Arthropod Food Web on Plants. Experimental and Applied Acarology 25(10): 785-808.

Vierbergen G., KuCharczyK H., KiRK W.D.J. 2010. A key to the second instar larvae of the Thripidae of the Western Palaearctic region (Thysanoptera). Tijdschrift voor Entomologie 153(1): 99-160.

Weintraub P., Pivona S., Steinberg S. 2011. How many Orius laevigatus are needed for effective western flower thrips, Frankliniella occidentalis, management in sweet pepper? Crop protection 30(11): 1443-1448.

Wimmer D., Hoffmann D., Schausberger P. 2008. Prey suitability of western flower thrips, Frankliniella occidentalis, and onion thrips, Thrips tabaci, for the predatory mite Amblyseius swirskii. Biocontrol Science and Technology 18(6): 541-550.

WitTMann E.J., Leather S.R. 1997. Compatibility of Orius laevigatus FIEBER (Hemiptera: Anthocoridae) with Neoseiulus (Amblyseius) cucumeris OudEMANs (Acari: Phytoseiidae) and Iphiseius (Amblyseius) degenerans BERLESE (Acari: Phytoseiidae) in the biocontrol of Frankliniella occidentalis PERGANDE (Thysanoptera: Thripidae). Experimental and Applied Acarology 21(8): 523-538.

Xu X., EnkegaArd A. 2010. Prey preference of the predatory mite, Amblyseius swirskii between first instar western flower thrips Frankliniella occidentalis and nymphs of the two-spotted spider mite Tetranychus urticae. Journal of Insect Science 10(149): 1-11.

Received: 21 October 2015

Accepted: 23 September 2016 